\title{
Preparation and Quantitative Determination of Antibodies Against Major Outer Membrane Proteins of Escherichia coli $\mathrm{O} 26 \mathrm{~K} 60$
}

\author{
By H. HOFSTRA* AND J. DANKERT \\ Laboratory for Medical Microbiology, State University Groningen and \\ Department of Hospital Infections, University Hospital A.Z.G., Groningen, \\ Oostersingel 59, 9713 EZ, The Netherlands
}

(Received 14 August 1979)

\begin{abstract}
Antisera against isolated outer membrane (OM) proteins I and $\mathrm{II}^{*}$ of Escherichia coli O26 K60 were elicited in rabbits. Antisera obtained after intramuscular administration with Freund's complete adjuvant showed high titres of specific antibodies. Intravenous administration of the same preparations yielded a considerable antibody response against bacterial lipopolysaccharide, a minor contaminant of the protein preparations. Antibody titres against $\mathrm{OM}$ proteins $\mathrm{I}$ and $\mathrm{II}^{*}$, lipopolysaccharide and murein-lipoprotein were determined by the enzyme-linked immunosorbent assay (ELISA) in these sera, and in antisera elicited against whole formaldehyde-fixed bacteria or isolated OM. Comparison of ELISA with single radial immunodiffusion and interfacial immunoprecipitation tests revealed that ELISA was not only the most uniformly applicable, but also the most specific and the most convenient method. In double diffusion tests no cross-reactivity between proteins I and II* was seen. Antibodies against proteins I and $\mathrm{II}^{*}$, lipopolysaccharide and lipoprotein could be specifically absorbed from the sera with the appropriate antigen preparations. Absorption experiments with intact E. coli $026 \mathrm{~K} 60$, Tris/EDTA-sheared bacteria and isolated OM revealed that antibodies against protein I were hardly absorbed at all probably because the antibody, evoked against denatured protein I, did not react with the protein in its native configuration. Antibodies against protein II* and lipoprotein were absorbed by intact as well as by sheared bacteria, but to a much greater extent by isolated $\mathrm{OM}$, which indicates that these $\mathrm{OM}$ components are accessible from the outside, but that they are situated relatively deep in the OM structure.
\end{abstract}

\section{INTRODUCTION}

The outer membrane (OM) of Escherichia coli contains a number of major proteins in the 27000 to 41000 molecular weight range, designated Ia, Ib (Schmitges \& Henning, 1976) and II* (Garten et al., 1975) or b, c and d (Lugtenberg et al., 1975). Another major OM constituent is the murein-bound or free lipoprotein (Braun \& Rehn, 1969). The function of $\mathrm{OM}$ proteins in the immunology of Gram-negative bacteria is not yet fully understood. Their immunological investigation requires the purification of these antigens and the development of reliable techniques to determine antibodies against them. Braun et al. (1976) determined antibodies against the lipoprotein by passive haemagglutination. The enzyme-linked immunosorbent assay was applied by Sippel et al. (1978) for the detection of antibodies against cell envelope proteins of Neisseria meningitidis and Salmonella typhi. Studying phage reception by OM proteins, Diedrich et al. (1977) and Chai \& Foulds (1979) used antibodies against the isolated proteins, the specificity of which 
was determined by double diffusion in agarose. Other methods applied for the detection of antibodies against OM proteins are immunoprecipitation (Inouye et al., 1976; Dankert \& Hofstra, 1978) and crossed immunoelectrophoresis (Van Tol et al., 1979).

In this study we report the quantitative determination of antibodies against $\mathrm{OM}$ proteins I and II*, lipopolysaccharide and murein-lipoprotein of E. coli $\mathrm{O} 26 \mathrm{~K} 60$ by single radial immunodiffusion (SRID) and enzyme-linked immunosorbent assay (ELISA). Purified protein preparations were administered to rabbits intravenously and intramuscularly to study the effect of the route of administration of these antigens on the immune response. The specificity of the antisera was investigated by double diffusion and interfacial immunoprecipitation. The affinity of the antibodies for the antigens in their native situation was studied by absorption experiments with intact or Tris/EDTA-sheared E. coli O26 K60 or isolated OM.

\section{METHODS}

Bacterial strains and growth conditions. Escherichia coli serotype $\mathrm{O} 26 \mathrm{~K} 60$ was maintained and grown as described previously (Dankert \& Hofstra, 1978). Escherichia coli JE5513, a lipoprotein-negative mutant strain derived from JE5512 (Hirota et al., 1977), was generously donated by Dr B. Lugtenberg, Utrecht, The Netherlands. It was maintained and grown in the same way as E. coli $\mathrm{O} 26 \mathrm{~K} 60$.

Extraction of membrane proteins. Outer membranes (OM) of E. coli $\mathrm{O} 26 \mathrm{~K} 60$ were prepared as described by Dankert \& Hofstra (1978). The major OM proteins were extracted by a procedure based on the method of Reithmeier \& Bragg (1974) for protein II* and of Rosenbusch (1974) for protein I. Protein II* was extracted from $200 \mathrm{mg}$ OM in $50 \mathrm{ml} 0.05 \mathrm{M}$-Tris $/ \mathrm{HCl}$ buffer $(\mathrm{pH} 7.8)$ containing $0.5 \%(\mathrm{w} / \mathrm{v})$ sodium dodecyl sulphate (SDS). This suspension was incubated for $1 \mathrm{~h}$ at $37^{\circ} \mathrm{C}$. After ultracentrifugation $\left(100000 \mathrm{~g}, 45 \mathrm{~min}, 15^{\circ} \mathrm{C}\right.$; Hereaus, Osterode, F.R.G.) the supernatant was concentrated to $10 \mathrm{ml}$ by ultrafiltration (PM10; Amicon, Lexington, U.S.A.) and precipitated with acetone $(90 \%, \mathrm{v} / \mathrm{v})$ at $-20^{\circ} \mathrm{C}$ for $18 \mathrm{~h}$. The precipitate was washed twice with ice-cold acetone $(90 \%, \mathrm{v} / \mathrm{v})$ and freeze-dried. The sediment of the first ultracentrifugation was re-extracted twice with the same volume of $0.05 \mathrm{M}-\mathrm{Tris} / \mathrm{HCl}(\mathrm{pH} 7.8)$ containing $1.0 \%(\mathrm{w} / \mathrm{v})$ SDS $\left(1 \mathrm{~h}, 37^{\circ} \mathrm{C}\right)$ to remove the rest of the protein $\mathrm{II}^{*}$. The supernatants of these extractions were discarded. Protein I was extracted from the remaining pellet with the same volume of $0.05 \mathrm{M}$-Tris/ $\mathrm{HCl}(\mathrm{pH} 7.8)$ containing $2.0 \%$ (w/v) SDS $\left(5 \mathrm{~min}, 100^{\circ} \mathrm{C}\right.$ ), followed by ultracentrifugation. The supernatant was concentrated, precipitated, washed and lyophilized as described above. The final pellet containing murein-lipoprotein (Braun \& Rehn, 1969) was re-extracted with $4 \%(\mathrm{w} / \mathrm{v})$ SDS $(1 \mathrm{~h}$, $100{ }^{\circ} \mathrm{C}$ ) to remove any remaining protein $\mathrm{I}$, washed twice with distilled water and freeze-dried.

Isolation of lipopolysaccharide (LPS). LPS of E. coli $\mathrm{O} 26 \mathrm{~K} 60$ was isolated according to Westphal et al. (1952) as described previously (Hofstra \& Dankert, 1979).

Isolation of lipoprotein-free murein. Outer membranes of $E$. coli JE5513, prepared as described for $E$. coli $\mathrm{O} 26 \mathrm{~K} 60$, were boiled in $0.05 \mathrm{M}-\mathrm{Tris} / \mathrm{HCl}(\mathrm{pH} 7.8)$ containing $4 \%(\mathrm{w} / \mathrm{v}) \mathrm{SDS}$ for $1 \mathrm{~h}$, followed by ultracentrifugation. The pellet was re-extracted, washed twice with distilled water and freeze-dried.

Column chromatography. The extracted OM protein fractions were purified by chromatography on a $5 \overline{\times} 60 \mathrm{~cm}$ column with water jacket (LKB, Bromma, Sweden) filled with Biogel P-150 (Bio-Rad, Richmond, U.S.A.). The elution buffer was $0.01 \mathrm{M}-\mathrm{Tris} / \mathrm{HCl}(\mathrm{pH} 7 \cdot 8)$ containing $0.25 \%(\mathrm{w} / \mathrm{v}) \mathrm{SDS}$. The elution rate was $25 \mathrm{ml} \mathrm{h}^{-1}$ at $28^{\circ} \mathrm{C}$ or $50 \mathrm{ml} \mathrm{h}^{-1}$ at $56{ }^{\circ} \mathrm{C}$. Samples $(5 \mathrm{ml})$ were collected with an LKB sample collector. Absorptions were followed at 206 and $280 \mathrm{~nm}$ (Uvicord III, LKB). Crude protein II* was solubilized at room temperature in elution buffer $\left(10 \mathrm{mg} \mathrm{ml}^{-1}\right)$, applied to the column and chromatographed at $28 \mathrm{C}$. Fractions containing the peak of protein $\mathrm{II}^{*}$ were pooled, concentrated to $10 \mathrm{ml}$ by ultrafiltration and precipitated with ice-cold acetone. Crude protein I was solubilized at $100{ }^{\circ} \mathrm{C}$ in elution buffer $\left(5\right.$ to $\left.10 \mathrm{mg} \mathrm{ml}^{-1}\right)$ and chromatographed at $56^{\circ} \mathrm{C}$. Fractions containing protein I were pooled, concentrated and precipitated with ice-cold acetone. Chromatography of the fractions containing protein I or II* was repeated three times.

Preparation of antisera. Antisera against formaldehyde-fixed bacteria and isolated OM were prepared as reported previously (Dankert \& Hofstra, 1978). Antisera against the isolated OM proteins were elicited by intravenous (i.v.) or intramuscular (i.m.) administration of the antigens. Two pairs of rabbits received four i.v. injections with increasing doses $(0.5,1 \cdot 0,1.5$ and $2.0 \mathrm{ml})$ of protein $\mathrm{I}$ or $1 I^{*}\left[1 \mathrm{mg} \mathrm{ml}^{-1}\right.$ in $0.9 \%$ $(\mathrm{w} / \mathrm{v}) \mathrm{NaCl}]$ at $5 \mathrm{~d}$ intervals. Two other pairs received $5 \mathrm{mg}$ protein I or II*, respectively, suspended in $0.5 \mathrm{ml} 0.9 \%(\mathrm{w} / \mathrm{v}) \mathrm{NaCl}$ and the same amount of Freund's complete adjuvant. The antigens were administered (i.m.) in the upper hindleg region on days 0 and 28. Blood was collected from all rabbits 2 to 3 weeks after the last injection. Sera were obtained by centrifugation of the clotted blood and stored at $-70^{\circ} \mathrm{C}$. 
Absorption of antisera. To remove antibodies directed against $E$. coli $\mathrm{O} 26 \mathrm{LPS}$, a $10 \mathrm{mg} \mathrm{ml}^{-1}$ solution of LPS O26 in phosphate-buffered saline (PBS; pH 7.2) was added to the sera (Hofstra \& Dankert, 1979). Specific absorption of antisera with the isolated OM proteins I or $\mathrm{II}^{*}$, murein-lipoprotein or lipoprotein-free murein was carried out by stepwise addition of one or more of these antigens, suspended in PBS to a concentration of $10 \mathrm{mg} \mathrm{ml}^{-1}$. Each addition was followed by incubation $\left(30 \mathrm{~min}, 37^{\circ} \mathrm{C}\right)$ and centrifugation $(10 \mathrm{~min}, 10000 \mathrm{~g}$ ) to remove immunecomplexes. To test the adherence of antibodies to the outermost layer of E. coli $\mathrm{O} 26 \mathrm{~K} 60,1 \mathrm{ml}$ samples of the antisera, undiluted or diluted $1: 20$ and $1: 80$ with PBS, were subjected to ten successive incubations with approximately $2 \times 10^{9}$ bacteria, untreated or sheared in Tris/ EDTA (Dankert \& Hofstra, 1978). Each incubation ( $20 \mathrm{~min}$, room temperature) was followed by centrifugation $(10 \mathrm{~min}, 8000 \mathrm{~g})$ to remove the bacteria. To test the adherence of antibodies to isolated OM of E. coli $\mathrm{O} 26 \mathrm{~K} 60$, antisera were incubated with $5 \mathrm{mg}$ freeze-dried $\mathrm{OM}(\mathrm{ml} \mathrm{serum})^{-1}$. After incubation for $1 \mathrm{~h}$ at room temperature the sera were centrifuged $(20 \mathrm{~min}, 12000 \mathrm{~g})$ to remove $\mathrm{OM}$ and absorbed antibodies.

Immunodiffusion. Double diffusion (Ouchterlony, 1958) was performed on glass slides in $0.5 \%(\mathrm{w} / \mathrm{v})$ agarose (Hoechst, Frankfurt, F.R.G.) in PBS (pH 7.2). LPS O26 was dissolved in PBS to a concentration of $1 \mathrm{mg} \mathrm{ml}^{-1}$. Proteins I and $\mathrm{II}^{*}$ were dispersed to the same concentration in PBS containing $0.2 \%(\mathrm{w} / \mathrm{v})$ SDS. Centre wells were filled with undiluted antisera $(20 \mu \mathrm{l})$ or with LPS-absorbed sera $(30 \mu \mathrm{l})$, and $30 \mu \mathrm{l}$ of the antigen preparations were added to the other wells. After incubation ( $24 \mathrm{~h}$, room temperature), plates were washed with PBS for $48 \mathrm{~h}$ at $4{ }^{\circ} \mathrm{C}$. The agarose was covered with several sheets of filter paper, dried under mild pressure, stained with Amido Black $[0.5 \%(\mathrm{w} / \mathrm{v})$ in $0.5 \%(\mathrm{v} / \mathrm{v})$ acetic acid] and destained with $0.5 \%(\mathrm{v} / \mathrm{v})$ acetic acid. Immunodiffusion patterns were photographed on Agfa Ortho 25 Professional document copying film.

Single radial immunodiffusion (SRID). SRID was carried out essentially as described by Vaerman et al. (1969). The antigens were dispersed in separate lots of PBS containing $2 \%(w / v)$ SDS to a concentration of $1 \mathrm{mg} \mathrm{ml}^{-1}$. LPS dissolved very well, protein I had to be solubilized by boiling for $5 \mathrm{~min}$ in this solvent, while protein II* $^{*}$ was dispersed sonically to a clear solution. These antigen solutions were added to separate $20 \mathrm{ml}$ quantities of $0.8 \%(\mathrm{w} / \mathrm{v})$ agarose (Hoechst) in PBS kept liquid at $50{ }^{\circ} \mathrm{C}$, the final concentrations being $50 \mu \mathrm{g}$ antigen $\mathrm{ml}^{-1}$ and approximately $0.1 \%$ (w/v) SDS. The agarose was poured into Petri dishes $\left(940 \mathrm{~cm}^{2}\right)$ to an antigen concentration of approximately $10 \mu \mathrm{g} \mathrm{cm}^{-2}$. Wells $\left(4 \mathrm{~mm}^{2}\right)$ were cut out and filled with $20 \mu \mathrm{I}$ of the undiluted antisera or $30 \mu \mathrm{l}$ of LPS-absorbed sera. Plates were incubated for $36 \mathrm{~h}$ at room temperature and then washed with several changes of fresh PBS $\left(72 \mathrm{~h}, 4^{\circ} \mathrm{C}\right)$. Plates were dried and stained as described above. After staining the total area enclosed by the precipitation ring was calculated.

Enzyme-linked immunosorbent assay (ELISA). ELISA was carried out essentially according to Engvall \& PerImann (1972), using the conjugate and substrate system described by Ruitenberg et al. (1974). Antigens (LPS, protein I, protein $\mathrm{II}^{*}$ or murein-lipoprotein) were dispersed in $0.1 \mathrm{M}-\mathrm{Na}_{2} \mathrm{CO}_{3}(\mathrm{pH} 9 \cdot 6)$ to a concentration of $30 \mu \mathrm{g} \mathrm{ml}^{-1}$. Disposable polystyrene microtitre trays (M-24-AR; Greiner, Nürtingen, F.R.G.) were filled with antigen suspensions $\left(100 \mu \mathrm{l}\right.$ per well) and incubated for $3 \mathrm{~h}$ at $37^{\circ} \mathrm{C}$. Non-attached antigen was removed by three washings with tap water. Dilution series of the rabbit antisera were made with PBS containing $1 \%(\mathrm{w} / \mathrm{v})$ bovine serum albumin (BSA) and $0.05 \%(\mathrm{v} / \mathrm{v})$ Tween 20 (PBS-BSA-Tween). Wells were filled with $100 \mu \mathrm{l}$ of diluted serum. Trays were incubated for $2 \mathrm{~h}$ at $37^{\circ} \mathrm{C}$. After three washings with tap water, $100 \mu \mathrm{l}$ of goat anti-rabbit IgG conjugated with horseradish peroxidase (Nordic, Tilburg, The Netherlands) diluted 1:1250 with PBS-BSA-Tween, was added to each well, followed by $2 \mathrm{~h}$ incubation at room temperature. Trays were washed as described above and $100 \mu \mathrm{l}$ of peroxidase substrate solution was applied to each well. Peroxidase substrate was composed of $100 \mathrm{ml}$ distilled water, $80 \mathrm{mg} 5$-aminosalicylic acid (Merck, Darmstadt, F.R.G.) and $16 \mu 1 \mathrm{H}_{2} \mathrm{O}_{2}(30 \%$, v/v). The $\mathrm{pH}$ was adjusted to 6.0 with $\mathrm{NaOH}$. The reaction was developed for $30 \mathrm{~min}$ at room temperature. The endpoint titre was determined visually, being the highest serum dilution giving a positive colour development. Antiserum dilution series applied to uncoated wells and PBS-BSA-Tween (not containing antiserum) added to antigen-coated wells were used as negative controls.

Interfacial immunoprecipitin test (IIP). This test was carried out essentially as reported by Dankert \& Hofstra (1978). OM of E. coli O26 K60 were solubilized by boiling for $5 \mathrm{~min}$ in PBS containing $2 \%(\mathrm{w} / \mathrm{v}$ ) SDS, followed by dilution to $0.2 \%(\mathrm{w} / \mathrm{v}) \mathrm{SDS}$, the final OM concentration being $1 \mathrm{mg} \mathrm{ml}^{-1}$. This preparation was reacted with LPS-absorbed antisera against whole bacteria, isolated OM or purified OM proteins. Immunoprecipitates were analysed by SDS-polyacrylamide gel electrophoresis according to Laemmli (1970) on slab gels. Procedures for staining and destaining the gels have been described previously (Dankert \& Hofstra, 1978).

Determinations. Protein was estimated by the Lowry method and 2-keto-3-deoxyoctonate by the method of Ellwood (1970). Endotoxin activity was estimated by the Limulus lysate test (Yin et al., 1972) using Limulus amoebocyte preparation (Mallinckrodt, St Louis, U.S.A.) and related to a standard endotoxin reference (Sigma). Hexoses were determined by the anthrone method (Trevelyan \& Harrison, 1952). 


\section{RESULTS}

\section{Chemical properties of the E. coli $\mathrm{O} 26 \mathrm{~K} 60$ isolates}

After repeated column chromatography proteins I and II* seemed pure in SDSpolyacrylamide gel electrophoresis (PAGE). Protein I gave two bands - a dense band, representing subcomponent $\mathrm{Ib}$, and a very faint one of subcomponent Ia (designations after Schmitges \& Henning, 1976). When gels were overloaded (>100 //g protein per slot) a minute contamination with protein II* was detectable in our protein I preparation. No 2-keto-3-deoxyoctonate (KDO) could be detected in protein I, while the activity found with the Limulus lysate test corresponded to less than $0.5 \%(\mathrm{w} / \mathrm{w})$ endotoxin. Protein II* contained 0.3 to $0.5 \%$ (w/w) KDO while the Limulus lysate test indicated an endotoxin content of $0.5 \%(\mathrm{w} / \mathrm{w})$. Carbohydrates were not detectable in protein $\mathrm{I}$; the protein $\mathrm{II}^{*}$ preparation contained 4 to $5 \%(\mathrm{w} / \mathrm{w})$. The isolated LPS O26 (not free of nucleic acids) contained less than $1 \%(\mathrm{w} / \mathrm{w})$ protein. Jts carbohydrate content was 50 to $60^{\circ}{ }_{1}(\mathrm{w} / \mathrm{w})$ and its KDO content was 10 to $12 \%(\mathrm{w} / \mathrm{w})$. The murein-lipoprotein preparation showed no endotoxin activity in the Limulus lysate test. Analysis of this preparation by SDS-PAGE showed no protein bands.

\section{Double immunodiffusion}

Figure 1 shows the results of the double diffusion tests, using the antisera elicited by intravenous (i.v.) administration of whole formaldehyde-fixed E. coli $\mathrm{O} 26 \mathrm{~K} 60$, its isolated $\mathrm{OM}$ and proteins $\mathrm{I}$ and $\mathrm{II}^{*}$ or by intramuscular (i.m.) administration of the two OM protein preparations. The antisera obtained after i.v. injection of whole cells or isolated OM gave heavy precipitin lines with LPS O26 as well as with the LPS present in protein II* (Fig. $1 a$ and $c$ ). LPS absorption resulted in their disappearance. Only a faint precipitin line with protein $\mathrm{II}^{*}$ and an extremely faint line with protein I remained (Fig. $1 b$ and $d$ ). The antisera obtained after i.v. administration of proteins I and II* showed precipitin lines with LPS and the LPS-contaminant in protein $\mathrm{II}^{*}$ which disappeared after LPS absorption of the sera (Fig. $1 e, f, g$ and $h$ ). After this absorption only anti-II* serum gave a faint line with its specific antigen (Fig. $1 h$ ). The antisera resulting from i.m. administration of the isolated proteins I and II* with Freund's complete adjuvant showed heavy precipitin lines with their specific antigens (Fig. $1 i$ and $k$ ). The antiserum against protein I gave no precipitin line with LPS. Consequently, LPS absorption did not affect the pattern obtained with this serum (Fig. $1 j$ ). The antiserum against protein II* gave a weak line with LPS which could be removed by LPS absorption (Fig. $1 l$ ). Cross-reactivity between proteins I and II* was not observed.

\section{Single radial immunodiffusion}

In SRID experiments, LPS-absorbed antisera were applied to agarose plates containing proteins I or II*. The antisera against isolated OM or whole bacteria reacted only weakly with protein I and moderately with protein II* (Table 1). Antisera elicited by i.m. administration of proteins I and $\mathrm{II}^{*}$ gave large precipitation rings when reacted with their specific antigens $\left(132.3\right.$ and $147.8 \mathrm{~mm}^{2}$ for protein I and protein $\mathrm{II}^{*}$, respectively). The antisera raised by i.v. administration of the proteins were less reactive. All antisera which had not been absorbed with LPS gave considerable precipitin areas when applied to LPS-containing plates.

\section{Enzyme-linked immunosorbent assay}

Antisera against formaldehyde-fixed $E$. coli $\mathrm{O} 26 \mathrm{~K} 60$ or against isolated $\mathrm{OM}$ of this serotype contained high titres of antibodies against LPS O26, which were effectively removed by absorption (Table 2). Lower titres against proteins I and $\mathrm{II}^{*}$ and against murein-lipoprotein were detected in these sera. The antibody titre against murein-lipo- 


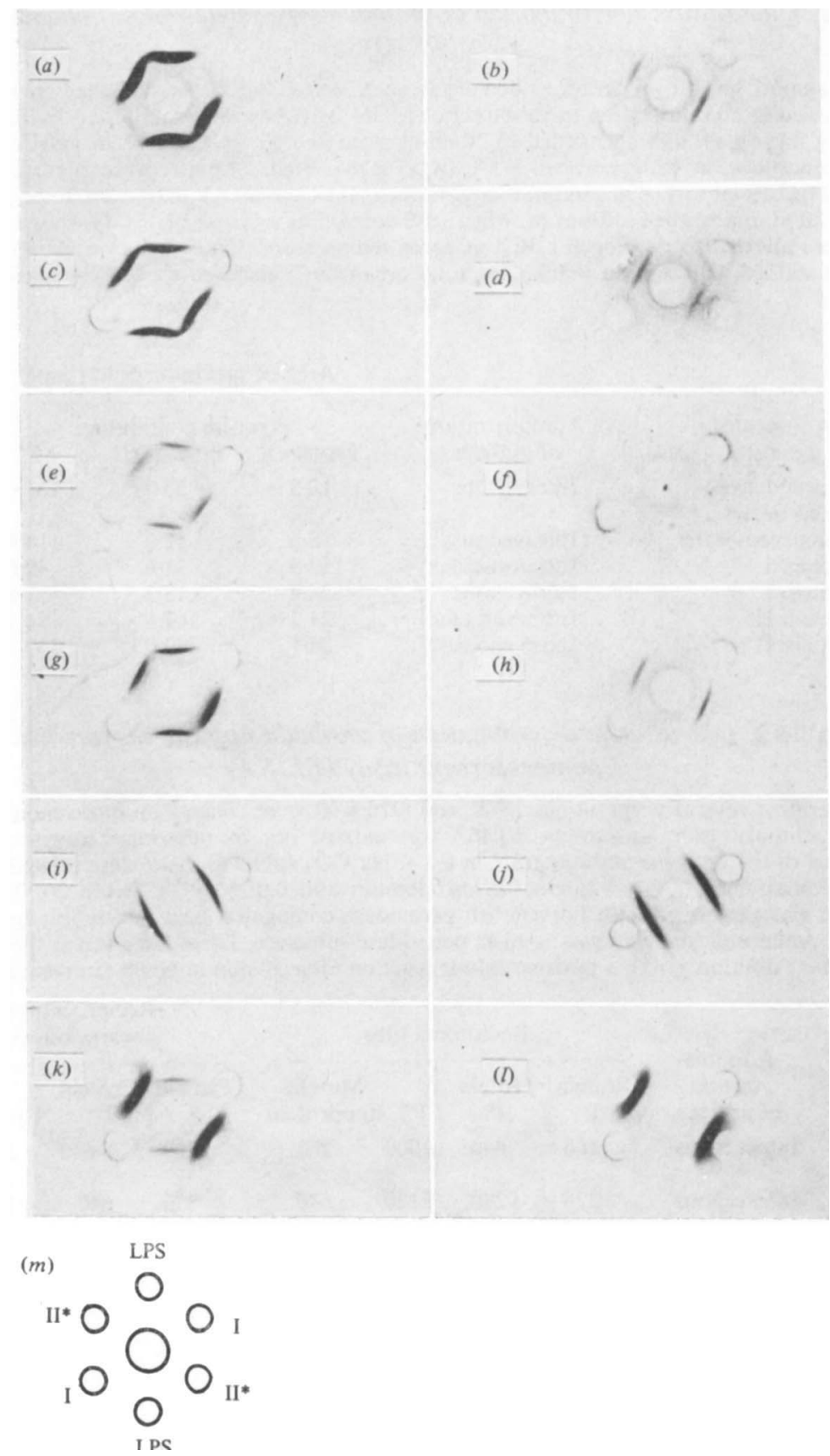

Fig. 1. Double diffusion patterns obtained with rabbit antisera against several preparations of E. coli $\mathrm{O} 26 \mathrm{~K} 60$ and antigenic preparations of the same strain. Peripheral wells were filled with $30 \mu 1$ of solutions ( $1 \mathrm{mg} \mathrm{ml}^{-1}$ ) of LPS (top and bottom wells), protein I (upper right and lower left) or protein II* (upper left and lower right) as indicated in $(m)$. Centre wells were filled with $20 \mu \mathrm{l}$ of antisera against: formaldehyde-fixed cells of $E$. coli $\mathrm{O} 26 \mathrm{~K} 60(a)$; isolated OM (c); protein I, administered intravenously (i.v.) (e); protein $\mathrm{II}^{*}$, i.v. $(g)$; protein $\mathrm{I}$, administered intramuscularly (i.m.) (i) and protein II*, i.m. $(k)$. Centre wells of the right hand column $(b$ to $l)$ were filled with $30 \mu 1$ of the same sera after absorption with LPS of $E$. coli O26 K60. Precipitin lines were allowed to develop for $24 \mathrm{~h}$ at room temperature. Plates were washed with PBS $\left(48 \mathrm{~h}, 4{ }^{\circ} \mathrm{C}\right.$ ), dried and stained with Amido Black. 
Table 1. Quantitative determination of antibodies by single radial immunodiffusion $(S R I D)$

Antisera against several preparations derived from $E$. coli $\mathrm{O} 26 \mathrm{~K} 60$ were elicited by intravenous or intramuscular administration to rabbits. For SRID, antigens were solubilized in PBS (pH 7.2) containing $2 \%(\mathrm{w} / \mathrm{v})$ SDS and added to $20 \mathrm{ml}$ agarose $(0.8 \%$, w/v) in PBS in Petri dishes [final antigen concentration $10 \mu \mathrm{g} \mathrm{cm}^{-2}$ in $\left.0 \cdot 1 \%(\mathrm{w} / \mathrm{v}) \mathrm{SDS}\right]$. Wells $\left(4 \mathrm{~mm}^{2}\right)$ were cut out and filled with $30 \mu \mathrm{l}$ of LPS-absorbed antiserum if antibodies against proteins I or II* were to be determined and with $20 \mu \mathrm{l}$ unabsorbed antiserum, when LPS-containing agarose plates were used. Precipitin haloes were allowed to develop for $36 \mathrm{~h}$ at room temperature. Plates were washed ( $72 \mathrm{~h}, 4 \mathrm{C}$ ), dried and stained with Amido Black. The total area $\left(\mathrm{mm}^{2}\right)$ enclosed by the precipitin halo was calculated.

\begin{tabular}{|c|c|c|c|c|}
\hline \multirow{3}{*}{$\begin{array}{l}\text { Antiserum } \\
\text { against: }\end{array}$} & \multirow{3}{*}{$\begin{array}{l}\text { Administration } \\
\text { of antigen }\end{array}$} & \multicolumn{3}{|c|}{ Area of precipitin halo $\left(\mathrm{mm}^{2}\right)$} \\
\hline & & \multicolumn{3}{|c|}{ Agarose containing: } \\
\hline & & Protein I & Protein $\amalg^{*}$ & LPS \\
\hline $\begin{array}{l}\text { Formaldehyde- } \\
\text { fixed bacteria }\end{array}$ & Intravenous & $12 \cdot 3$ & $35 \cdot 7$ & $137 \cdot 6$ \\
\hline Outer membrane & Intravenous & $18 \cdot 6$ & $37 \cdot 2$ & $118 \cdot 8$ \\
\hline Protein I & Intramuscular & $132 \cdot 3$ & $21 \cdot 6$ & $49 \cdot 0$ \\
\hline Protein I & Intravenous & $28 \cdot 4$ & $13 \cdot 3$ & $51 \cdot 6$ \\
\hline Protein $\mathrm{II}^{*}$ & Intramuscular & $24 \cdot 2$ & $147 \cdot 8$ & $84 \cdot 3$ \\
\hline Protein II* & Intravenous & $24 \cdot 1$ & $49 \cdot 0$ & $100 \cdot 7$ \\
\hline
\end{tabular}

Table 2. Quantitative determination of antibodies by the enzyme-linked immunosorbent assay (ELISA)

Antisera against several preparations of $E$. coli $026 \mathrm{~K} 60$ were elicited by intravenous or intramuscular administration to rabbits. ELISA was carried out in microtitre trays coated with suspensions of the antigens at $30 \mu \mathrm{g} \mathrm{ml}^{-1}$ in $0 \cdot 1 \mathrm{M}-\mathrm{Na}_{2} \mathrm{CO}_{3}(\mathrm{pH} 9 \cdot 6$ ). Sera were diluted with PBS (pH 7.2) containing $1 \%(\mathrm{w} / \mathrm{v})$ bovine serum albumin and $0.05 \%(\mathrm{v} / \mathrm{v})$ Tween 20 . The second incubation was performed with horseradish peroxidase conjugated goat anti-rabbit IgG, diluted $1: 1250$. 5-Aminosalicylic acid was used as peroxidase substrate. Titres are given as the reciprocal of the highest dilution giving a positive colour reaction after $30 \mathrm{~min}$ at room temperature.

\begin{tabular}{|c|c|c|c|c|c|c|c|c|c|}
\hline \multirow[b]{2}{*}{$\begin{array}{l}\text { Antiserum } \\
\text { against: }\end{array}$} & \multirow{2}{*}{$\begin{array}{l}\text { Adminis- } \\
\text { tration } \\
\text { of antigen }\end{array}$} & \multicolumn{4}{|c|}{ Reciprocal titre } & \multicolumn{4}{|c|}{$\begin{array}{l}\text { Reciprocal titre after } \\
\text { absorption with LPS }\end{array}$} \\
\hline & & $\begin{array}{l}\text { Protein } \\
\text { I }\end{array}$ & $\begin{array}{l}\text { Protein } \\
\amalg^{*}\end{array}$ & LPS & $\begin{array}{l}\text { Murein- } \\
\text { lipoprotein }\end{array}$ & $\begin{array}{c}\text { Protein } \\
\text { I }\end{array}$ & $\begin{array}{l}\text { Protein } \\
\text { II }^{*}\end{array}$ & LPS & $\begin{array}{l}\text { Murein- } \\
\text { lipoprotein }\end{array}$ \\
\hline $\begin{array}{l}\text { Formaldehyde- } \\
\text { fixed bacteria }\end{array}$ & Intravenous & 160 & 640 & 10000 & 160 & 160 & $320-640$ & $<20$ & 160 \\
\hline $\begin{array}{l}\text { Outer } \\
\text { membrane }\end{array}$ & Intravenous & 320 & 1280 & 5120 & 640 & 320 & 640 & $<20$ & 640 \\
\hline Protein I & Intramuscular & 20000 & 320 & 160 & 2560 & 20000 & $160-320$ & $<20$ & 2560 \\
\hline & Intravenous & 640 & & 320 & & 640 & 320 & $<20$ & 160 \\
\hline & Intramuscular & 160 & 160000 & 320 & $<2$ & 160 & 160000 & $<20$ & $<20$ \\
\hline Protein II* & Intravenous & 160 & 1280 & 2560 & $<20$ & 160 & $640-1280$ & $<20$ & $<20$ \\
\hline
\end{tabular}

protein was higher in the antiserum against isolated OM than in the serum against whole bacteria. The antisera elicited after i.m. administration of proteins I and II* showed high titres of antibodies against their appropriate antigens and low titres against LPS. A marked antibody content against murein-lipoprotein was only detected in the antiserum against protein I. The antisera formed after i.v. administration of proteins I and II* showed low titres against their appropriate antigens. In the anti-protein I serum a relatively high antibody titre against protein II* was found, though protein II* was only a minor contaminant of the protein I preparation. Antibodies against LPS were present in both sera; in that against protein II* the titre even exceeded that against the protein itself. 


\section{Table 3. Specific absorption of antibodies from sera against outer membrane proteins of E. coli $\mathrm{O} 26 \mathrm{~K} 60$}

Antisera against outer membrane proteins I and II* were elicited by intramuscular administration of the antigens to rabbits. Absorptions were carried out by stepwise addition of proteins I and II*, murein-lipoprotein of $E$. coli $\mathrm{O} 26 \mathrm{~K} 60$ or lipoprotein-free murein of $E$. coli JE5513, suspended in PBS to $10 \mathrm{mg} \mathrm{ml}^{-1}$. Absorptions were continued until visible immunoprecipitates were no longer formed. Immunoprecipitates were removed by centrifugation $(10 \mathrm{~min}, 10000 \mathrm{~g})$. ELISA was performed as described in the legend to Table 2 .

\begin{tabular}{|c|c|}
\hline \multicolumn{2}{|r|}{ Antiserum } \\
\hline Elicited against: & Absorbed with: \\
\hline Protein I & $-\dagger$ \\
\hline Protein 1 & Protein I $\uparrow$ \\
\hline Protein I & Murein-lipoprotein $\mathrm{O} 26 \dagger$ \\
\hline Protein I & Murein JE5513† \\
\hline Protein I & Protein I+ murein JE5513† \\
\hline Protein I & $\begin{array}{l}\text { Protein I+ } \\
\text { murein-lipoprotein } \mathrm{O} 26 \dagger\end{array}$ \\
\hline Protein II* & $-\ddagger$ \\
\hline Protein II* & Protein II* $\ddagger$ \\
\hline
\end{tabular}

\begin{tabular}{ccc}
\multicolumn{3}{c}{ Reciprocal titre } \\
Protein I & Protein II* & $\begin{array}{c}\text { Murein- } \\
\text { lipoprotein }\end{array}$ \\
20000 & 80 & 2560 \\
160 & 80 & 2560 \\
20000 & 80 & 20 \\
20000 & 80 & 2560 \\
$80-160$ & 80 & 2560 \\
80 & 80 & 20 \\
$80-160$ & 160000 & $<20$ \\
$80-160$ & 160 & $<20$
\end{tabular}

$\dagger$ Antiserum against protein I was absorbed with lipopolysaccharide O26 and protein II* before the absorptions described here.

$\ddagger$ Antiserum against protein $\mathrm{II}^{*}$ was absorbed with lipopolysaccharide $\mathrm{O} 26$ and protein I before the absorptions described here.

The specificity of the antibodies was tested by selective absorptions with several isolates of $E$. coli $\mathrm{O} 26 \mathrm{~K} 60$ or $E$. coli JE5513. Absorption of the antiserum against protein I with the same antigen suspended in PBS effectively removed the antibodies against protein I, but the titre against murein-lipoprotein remained unchanged (Table 3). Incubation of this antiserum with murein-lipoprotein of $E$. coli $\mathrm{O} 26 \mathrm{~K} 60$ absorbed the antibodies against this complex, without affecting the titre against protein I. Absorption with lipoprotein-free murein isolated from $E$. coli JE5513 showed that no antibodies directed against murein were involved. All antibody activity was removed by a combined absorption with protein I and murein-lipoprotein. Antibodies against protein II* were removed from the antiserum against this antigen with protein $\mathrm{II}^{*}$ suspended sonically in PBS.

Table 4 shows the results of absorption experiments carried out with whole cells of E. coli $\mathrm{O} 26 \mathrm{~K} 60$, bacteria sheared in Tris/EDTA or isolated OM. Antibodies against protein I were not absorbed to untreated or sheared bacteria and insignificantly to isolated OM. Antibodies against lipoprotein were absorbed to untreated as well as to sheared cells but were removed more effectively by incubation with isolated OM. The antibody titre against protein $\mathrm{II}^{*}$ decreased after absorption with whole or sheared bacteria, but absorption with isolated $\mathrm{OM}$ again gave the strongest reduction.

\section{Interfacial immunoprecipitation}

OM of E. coli $\mathrm{O} 26 \mathrm{~K} 60$, solubilized by boiling in $2 \%$ (w/v) SDS, followed by dilution to $0.2 \%(\mathrm{w} / \mathrm{v})$ SDS, was reacted in IIP tests with LPS-absorbed antisera. SDS-PAGE analysis of the immunoprecipitates revealed that those obtained with antisera against whole bacteria or isolated OM contained predominantly protein II* and much less protein I. The antiserum against protein I (i.m. administered) precipitated predominantly protein I, although a considerable quantity of protein $\mathrm{II}^{*}$ was also detected. Pre-absorption of this antiserum with protein $\mathrm{II}^{*}$ gave a decrease, though not a disappearance, of protein II* from the immunoprecipitates. Application of the antiserum against protein II* (i.m.

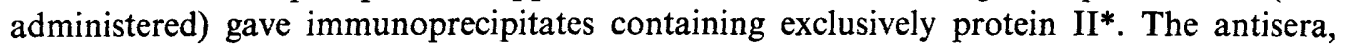




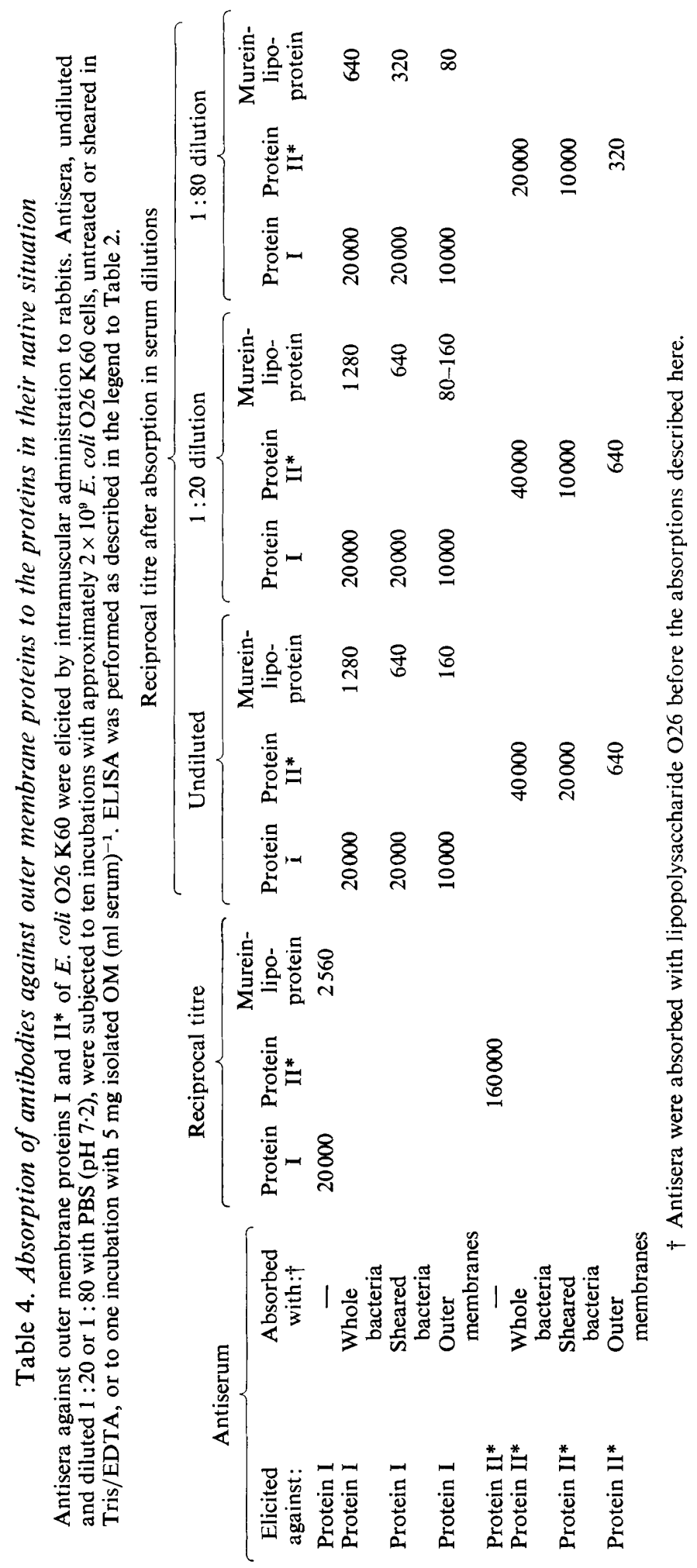


resulting from i.v. administration of protein $\mathrm{I}$ or $\mathrm{II}^{*}$ both precipitated a small amount of

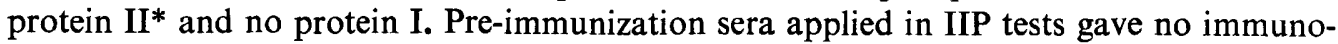
precipitation.

\section{DISCUSSION}

Our results show that high titres of antibodies against the major OM proteins I and II* of $E$. coli $\mathrm{O} 26 \mathrm{~K} 60$ were raised after intramuscular (i.m.) administration of the isolated proteins to rabbits. After intravenous (i.v.) administration of these preparations a very low antibody response to the proteins was found, while the titre against LPS was higher than expected. The significant presence of anti-LPS in these sera may be caused by the fact that the hydrophobic OM proteins acted as carriers for the contaminating LPS molecules. The hydrophilic polysaccharide O-chain of the LPS probably protruded from the proteinLPS complex, thus providing a highly immunogenic conformation for the $O$ antigen. Apart from this passive carrier function, the OM proteins might well have played a more active part in antibody formation against LPS. LPS-associated protein is known to stimulate murine lymphocytes in vitro (Sultzer \& Goodman, 1976; Betz \& Morrison, 1977) and to evoke the proliferation of rabbit splenic lymphocytes and human peripheral blood lymphocytes (Goodman \& Sultzer, $1979 a, b$ ), while protein-free LPS is inactive. The antibody response against the LPS in our protein preparations might indicate that protein II* and possibly protein I could be responsible for B-cell proliferation resulting in antibody synthesis, after priming with LPS by the first injections of the immunization series. This may also provide an explanation for the observation that i.v. administration of protein-free LPS did not evoke an anti-LPS response (results not shown). The low antibody response against the proteins after i.v. injection shows that these proteins are obviously poor immunogens after administration by this route, despite the particulate character of these hydrophobic antigens. The poor antibody response against the OM proteins after i.v. injection of whole bacteria or isolated OM may be due to inaccessibility as a result of LPS shielding the proteins (Hofstra et al., 1979).

After i.m. administration with Freund's complete adjuvant, the antigen is released very slowly from the i.m. depot. This may have prevented the antibody synthesis against the small amount of LPS, while antibody formation against the proteins was apparently effectively stimulated.

A considerable antibody titre against murein-lipoprotein was detectable in our antiserum against isolated protein I (i.m. administered), though this protein seemed electrophoretically pure. The fact that absorption of this antiserum with the same protein I preparation did not affect the antibody titre against murein-lipoprotein illustrates that protein I was only minutely contaminated with lipoprotein. The tight linkage between lipoprotein and the peptidoglycan-bound OM protein I (DeMartini \& Inouye, 1978) may prevent proper separation by column chromatography. Indeed, the antiserum against protein II* (not peptidoglycan-bound) was free from antibodies against lipoprotein, which excludes the presence of lipoprotein in this protein. In antiserum against $\mathrm{OM}$ the antibody titre against murein-lipoprotein was evidently higher than in the serum against whole cells. This corresponds to the findings of Braun et al. (1976) who found a relation between antibody formation against enterobacterial lipoprotein and the exposure of this antigen on several smooth and rough ( $\mathrm{Ra}-$ to $\mathrm{Re}-$ ) strains of various Enterobacteriaceae species.

The unusual character of hydrophobic OM proteins inhibits the application of the usual immunochemical methods (Salton \& Owen, 1976). Their insolubility requires the use of SDS as a solubilizing agent in methods based upon diffusion in agarose. Without the use of SDS our results obtained in double diffusion tests were insignificant. Non-immunological precipitation of antisera with SDS (Palmer et al., 1971; Cho \& Feng, 1974) is contradicted by the specificity of our precipitin lines. SRID led to a satisfactory estimation of antibody 
titres against OM proteins and LPS. However, without SDS, precipitation haloes were only seen with LPS. Attempts to detect antibodies against murein-lipoprotein in SRID with or without the use of SDS were unsuccessful. The ELISA system was the only method allowing standardization of the procedure irrespective of the chemical or physical nature of the antigens applied. Results of IIP experiments carried out with OM of E. coli O26 K60 boiled in SDS agreed with previous observations (Hofstra \& Dankert, 1979). However, IIP appeared to be not only less convenient, but also less specific than the other methods applied. The antiserum against protein I (i.m. administered) indeed precipitated predominantly protein I but also some protein II*, even after pre-absorption of this antiserum with protein II* $^{*}$. Thus some non-specific precipitation of protein II* in IIP cannot be excluded. As long as the isolated OM proteins and their specific antisera were not available, IIP was the most useful method for the immunological investigation of these antigens.

Our experiments showed that antibodies against LPS, lipoprotein and proteins I and II* could be specifically absorbed with the appropriate antigens solubilized or suspended in PBS. Absorptions to intact or sheared bacteria or isolated OM showed that anti-protein I was hardly absorbed or not at all. This indicates that protein I is buried too deep in the structure of the OM to be reached by its antibody, or that the antibody elicited against heat-denatured protein $I$ is not able to react with the antigen in its native configuration. Experiments carried out with an antiserum made against a new preparation of protein $I$, more resembling its native configuration, showed a significantly better absorption to whole bacteria or isolated OM (unpublished results). Heat denaturation of the antigen is probably the cause of the lack of absorption found in this study. Antibodies against protein $\mathrm{II}^{*}$ and lipoprotein were absorbed by intact or sheared bacteria, but the absorption to isolated OM was much stronger. This implies that the accessibility of these antigens to their specific antibodies is interfered with by other wall components, possibly LPS (Hofstra et al., 1979), or that these proteins are not located predominantly on the outer side of the OM. The localization on the OM has not yet been fully evaluated (DiRienzo et al., 1978). However, results of studies concerning phage reception by OM proteins (Datta et al., 1977; Van Alphen et al., 1977) and labelling by CNBr-activated dextran (Kamio \& Nikaido, 1977) indicate their accessibility on the outer surface of the bacteria. Our findings are in agreement with those of these workers although a relatively deep location is suggested by the fact that antibodies were absorbed significantly better by isolated OM than by (sheared) bacteria.

\section{REFERENCES}

Betz, S. J. \& Morrison, D. C. (1977). Chemical and biological properties of a protein-rich fraction of bacterial lipopolysaccharides. I. The in vitro murine lymphocyte response. Journal of Immuno$\log y$ 119, 1475-1481.

Braun, V. \& ReHN, K. (1969). Chemical characterization, spatial distribution and function of a lipoprotein (murein-lipoprotein) of the $E$. coli cell wall. The specific effect of trypsin on the membrane structure. European Journal of Biochemistry 10, 426-438.

Braun, V., Bosch, V., Klumpr, E. R., NefF, I., Mayer, H. \& Schlecht, S. (1976). Antigenic determinants of murein lipoprotein and its exposure at the surface of Enterobacteriaceae. European Journal of Biochemistry 62, 555-566.

ChaI, T.-J. \& Foulds, J. (1979). Inactivation of bacteriophages by protein $\mathrm{E}$, a new major membrane protein isolated from an Escherichia coli mutant. Journal of Bacteriology 137, 226-233.

CHo, C. T. \& FenG, K. K. (1974). Non-immuno- logical precipitation of serum by sodium dodecyl sulfate in agar diffusion. Applied Microbiology 28, $557-560$.

Dankert, J. \& Hofstra, H. (1978). Antibodies against outer membrane proteins in rabbit antisera prepared against Escherichia coli 026 K60. Journal of General Microbiology 104, 311-320.

Datta, D. B., Arden, B. \& Henning, U. (1977). Major proteins of the Escherichia coli outer cell envelope membrane as bacteriophage receptors. Journal of Bacteriology 131, 821-829.

DeMartini, M. \& INOUYe, M. (1978). Interaction between two major outer membrane proteins of Escherichia coli: the matrix protein and the lipoprotein. Journal of Bacteriology 133, 329-335.

Diedrich, D. L., Summers, A. O. \& Schnattman, C. A. (1977). Outer membrane proteins of Escherichia coli. V. Evidence that protein 1 and bacteriophage-directed protein 2 are different polypeptides. Journal of Bacteriology 131, 598607. 
DiRienzo, J. M., Nakamura, K. \& Inouye, M. (1978). The outer membrane proteins of Gramnegative bacteria: biosynthesis, assembly and functions. Annual Review of Biochemistry 47, 481-532.

Ellwood, D. C. (1970). The distribution of 2-keto3-deoxy-octonic acid in bacterial walls. Journal of General Microbiology 60, 373-380.

Engvall, E. \& PerlmanN, P. (1972). Enzymelinked immunosorbent assay, ELISA. III. Quantitation of specific antibodies by enzyme-labeled anti-immunoglobulin in antigen-coated tubes. Journal of Immunology 109, 129-135.

Garten, W., HindennaCH, I. \& Henning, U. (1975). The major proteins of the Escherichia coli outer cell envelope membrane. Characterization of proteins II* and III, comparison of all proteins. European Journal of Biochemistry 59, 215-221.

Goodman, G. W. \& Sultzer, B. M. (1979a). Endotoxin protein is a mitogen and polyclonal activator of human B-lymphocytes. Journal of Experimental Medicine 149, 713-723.

Goodman, G. W. \& Sultzer, B. M. (1979b). Further studies on the activation of lymphocytes by endotoxin protein. Journal of Immunology 122, 1329-1334.

Hirota, Y., Suzuki, H., Nishimura, Y. \& Yasuda, S. (1977). On the process of cellular division in Escherichia coli: a mutant of $E$. coli lacking a murein-lipoprotein. Proceedings of the National Academy of Sciences of the United States of America 74, 1417-1420.

Hofstra, H. \& DANKerT, J. (1979). Antigenic crossreactivity of major outer membrane proteins in Enterobacteriaceae species. Journal of General Microbiology 111, 293-302.

Hofstra, H., VAN Tol, M. J. D. \& Dankert, J. (1979). Immunofluorescent detection of the heatmodifiable major outer membrane protein II* in $^{*}$ Escherichia coli O26 K60. FEMS Microbiology Letters 6, 147-150.

Inouye, S., TAkeishi, K., Lee, N., DeMartini, M., Harashima, A. \& InOUye, M. (1976). Lipoprotein from the outer membrane of Escherichia coli: purification, paracrystallization and some properties of its free form. Journal of Bacteriology 127, 555-563.

Kamio, Y. \& NikaIDo, H. (1977). Outer membrane of Salmonella typhimurium. Identification of proteins exposed on the cell surface. Biochimica et biophysica acta 464, 589-601.

LAEMMLI, U. K. (1970). Cleavage of the structural proteins during the assembly of the head of bacteriophage T4. Nature, London 227, 680-685.

Lugtenberg, B., Meyers, J., Peters, R., VAN Der Hoek, P. \& VAN AlPhen, L. (1975). Electrophoretic resolution of the 'Major outer membrane protein' of Escherichia coli $\mathrm{K} 12$ into four bands. FEBS Letters 58, 254-258.

OUCHTERLONY, Ö. (1958). Diffusion-in-gel methods for immunological analysis. In Progress in Allergy, vol. 5, pp. 1-78. Edited by P. Kallós. Basel/New York: S. Karger.

Palmer, E. L., Martin, M. L., Hierholzer, J. C. \& ZIEGLER, D. W. (1971). Nonspecific precipitation of serum proteins by sodium lauryl sulfate in agar diffusion and immunoelectrophoresis. Applied Microbiology 21, 903-906.

ReithmeIer, R. A. F. \& BRAGG, P. D. (1974). Purification and characterization of a heatmodifiable protein from the outer membrane of Escherichia coli. FEBS Letters 41, 195-198.

RosenbusCH, J. P. (1974). Characterization of the major envelope protein from Escherichia coli. Regular arrangement on the peptidoglycan and unusual dodecyl sulfate binding. Journal of Biological Chemistry 249, 8019-8029.

RuitenberG, E. J., Steerenberg, P. A., Brosi, B. J. M. \& BuYs, J. (1974). Serodiagnosis of Trichinella spiralis infections in pigs by enzymelinked immunosorbent assays. Bulletin of the World Health Organization 51, 108-109.

Salton, M. R. J. \& OWen, P. (1976). Bacterial membrane structure. Annual Review of Microbiology 30, 451-482.

SChmitges, C. J. \& Henning, U. (1976). The major proteins of the Escherichia coli outer cell-envelope membrane. Heterogeneity of protein I. European Journal of Biochemistry 63, 47-52.

Sippel, J. E., Mamay, H. K., Weiss, E., Joseph, S. W. \& BEASLEY, W. J. (1978). Outer membrane protein antigens in an enzyme-linked immunosorbent assay for Salmonella enteric fever and meningococcal meningitis. Journal of Clinical Microbiology 7, 372-378.

Sultzer, B. M. \& Goodman, G. W. (1976). Endotoxin protein: a B-cell mitogen and polyclonal activator of $\mathrm{C} 3 \mathrm{H} / \mathrm{HeJ}$ lymphocytes. Journal of Experimental Medicine 144, 821-827.

Trevelyan, W. E. \& Harrison, J. S. (1952). Studies on yeast metabolism. I. Fractionation and microdetermination of cell carbohydrates. Biochemical Journal 50, 298-303.

VAERman, J. P., Lebace-Verheyden, A. M., Scolari, L. \& Heremans, J. F. (1969). Further studies on single radial immunodiffusion. II. The reversed system: diffusion of antibodies in antigencontaining gels. Immunochemistry 6, 287-291.

Van Alphen, L., Havekes, L. \& LugtenberG, B. (1977). Major outer membrane protein d of Escherichia coli K12. Purification and in vitro activity of bacteriophage $\mathrm{K} 3$ and $\mathrm{f}$-pilus mediated conjugation. FEBS Letters 75, 285-290.

Van Tol, M. J. D., Hofstra, H. \& Dankert, J. (1979). Major outer membrane proteins of Escherichia coli analysed by crossed immunoelectrophoresis. FEMS Microbiology Letters 5, 349-352.

Westphal, O., Lüderitz, O. \& BISTER, F. (1952). Über die Extraktion von Bakterien mit PhenolWasser. Zeitschrift für Naturforschung 7b, 148155.

Yin, E. T., Galanos, C., Kinsky, S., Bradshaw, R. A., Wessler, S., Lüderitz, O. \& Sarmiento, M. E. (1972). Picogram-sensitive assay for endotoxin: gelation of Limulus polyphemus blood cell lysate induced by purified lipopolysaccharides and lipid-A from Gram-negative bacteria. Biochimica et biophysica acta 261, 284-289. 